\title{
The Effectiveness of Teaching Using Virtual and Flipped Classrooms In Developing Achievement Among First Secondary Female Students on History in Qasr District
}

\author{
Ms. Ehteram Saleem Salman Allasasmeh \\ Jordan - Amman
}

\begin{abstract}
The study aimed to know the effectiveness of teaching using virtual classrooms and flipped classrooms in developing the achievement of first-year secondary students in the subject of history in Qasr District. To achieve the objectives of the study, the quasi-experimental approach was adopted, where the study was conducted on an experimental group consisting of (23) students who were taught through virtual classes and an experimental group consisting of (22) taught by flipped classrooms, where the choice was by the intentional way, they were distributed among two study divisions randomly from the first year secondary students Serfa Secondary School for the academic year 2020/2021 AD. To collect the study data, an achievement test was prepared. The validity and reliability of this tool were verified before its application and the results of the study showed that there were statistically significant differences in favor of flipped classes and development of achievement. According to the results of the study, the researcher recommends conducting more studies in the field of virtual classrooms and flipped classrooms.
\end{abstract}

Keywords: Achievement, Flipped Classes, Virtual Classes.

DOI: $10.7176 / \mathrm{JEP} / 12-31-05$

Publication date: November $30^{\text {th }} 2021$

\subsection{INTRODUCTION}

The current era is characterized tremendous amount of information and knowledge, a progress in the modern communication technology, and a rapid change in Scientific and technological Applications; That led to calling it the age of information. Learning has become online, or distance learning as a status que imposed by the recent changes that occur in the present age. to keep pace with changes and shifts, learners had become in need for selfskills that help them encounter variety of changes and adapt to them positively, and apply strategies keep up development in learning and teaching processes.

Electronic learning has rendered educational revival,and fast change, where it has been one of the most influential developments in teaching and learning.It gives students a chance as well as satisfaction to learn, , so e-learning environments have been divided into realistic environments, such as classrooms and computer labs, where teachers and students meet in the same place, and learning is done through a computer, the internet, or through virtual environments- electronic learning environments- that do not have a geographical location and learning is accomplished online such as virtual classes, virtual laboratories that can be implemented through special programs and websites on the internet (Sirkemaa), 2014).

Flipped learning is one of the e-learning environments in which web applications, videos or audio and ebooks are implemented in individual learning so that learners perform educational activities before starting the regular semester, so the e-learning environment allows learners to learn according to their own circumstances, providing flexible learning that the learner chooses time and place for learning, and the method of learning whether it is individual, independent, or group cooperative. In this strategy, the teacher shares videos he produces with his students, or chooses pre-prepared clips from YouTube, for example, that explain the topics of the lesson that he will teach, and although Videos are commonly usedfor flipped learning, this does not prevent the use of electronic presentations, interactive e-books, audio clips, or interaction with students through electronic forums (Al-Zain, 2015).

Educational institutions worldwide are encountering multiple and accelerating challenges. As a result of the rapid development and tremendous change in information and knowledge, and advancements in the field of modern technologies and communications. This change was not confined to the amount of knowledge, or the speed of update, but also included changing the ways of obtaining knowledge, and the focus has become on selflearning on the part of the learner rather than being a recipient. Therefore, it is important for the teacher to identify appropriate teaching methods for learners to suit their needs, tendencies and abilities, and at the same time respond immediately to developments in the field of information and communication technology to prepare a new generation that is more capable of addressing the developments and the challenges of the future (Al Oqab, 2018).

The researcher noticed, through her experience in teaching history for the secondary stage, poor achievement, and there was a weakness among female students in mastering historical concepts and knowledge. 
The problem of the study was that history material appeared as rigid excerpts that discourage students.It has also been noted that most of the common history teaching methods still focus on the traditional method. Perhaps this explains the rigidity of the history subject and the students' aversion, especially it depends on memorization and recalling information. Therefore, this study attempts to investigate the effectiveness of teaching using virtual and flipped classrooms in developing achievement among first secondary female students on history in Qasr district by answering the following question:

\section{-WERE THERE STATISTICALLY SIGNIFICANT DIFFERENCES $(\alpha=0.05)$ DEVELOPINGTHE FIRST SECONDARY FEMALE STUDENTS' ACHIEVEMENT IN HISTORY ATTRIBUTED TO THE TEACHING METHOD (VIRTUAL CLASSES, FLIPPED CLASSES)? 1.2 STUDY HYPOTHESES:}

This study seeks to test the following hypothesis:

There were no statistically significant differences $(\alpha \leq 0.05)$ in the first secondary female students' achievement in history that are attributed to the teaching method (virtual classes, flipped classes)?

\subsection{STUDY OBJECTIVES:}

This study sought to achieve the following:

1- Recognizing the effectiveness of virtual classrooms in developing the achievement of first secondary female students in history.

2- Recognizing the effectiveness of flipped classrooms in developing achievement towards learning among first secondary female students in history

\subsection{STUDY IMPORTANCE: 1.4}

1- The need to provide a framework on the strategy of virtual classrooms and flipped classrooms in teaching history for specialists, educators, researchers, educational supervisors and school administrators to benefit from while performing their supervisory duties where teachers are directed to adopt modern and appropriate teaching strategies, especially in light of distance learning in teaching history, to develop the strategies used in history at the secondary level.

2- Integrating modern technology into learning as a contemporary and important educational approach in education in general with the aim of mastering learning.

3- The practical importance helps in providing a procedural model for those concerned in the Ministry of Education to use the strategy of virtual classrooms and flipped classrooms in developing academic achievement in the history study when developing curricula, as well as identifying the actual situation for use in teaching.

\subsection{THE STUDY LIMITS:}

This study is limited to first- secondary female students at Al-Kerak Secondary School for Girls in Qasr Directorate of Education, Kerak Governorate, for the academic year 2020/2021. This study is also limited to teaching a unit of the history of Jordan book (Chapter One, Jordan in Early Islam, the Rashidun and Umayyad Era).

The accuracy of the limitations of the study tools were measured, and validity and reliability were confirmed.

PROCEDURAL DEFINITIONS:

-Virtual Classrooms: virtual classrooms are defined as a simulated online classroom; It provides a convenient environment for communication between distance learners, and provides a learning experience similar to real classrooms (CHadha, 2018).

It is procedurally defined in this study as classrooms similar to regular classrooms, where the teacher and student meet at Serfa Secondary School for Girls through distance learning, and at a specific time without place restriction, using tools and software connected to the Internet. Microsoft Teams) and PowerPoint presentations.

-Flipped classrooms: a method of teaching that is the opposite of traditional learning; where learners discover the learning material before the lesson, and class time is devoted to enhancing understanding through discussing learners of what they have learned, discussing activities to solve problems that are designed, and presented by the teacher (Sharama, A2018).

It is defined procedurally as a type of learning in which videos are recorded by Microsoft Teams and PowerPoint presentations or selection of video links from YouTube to be sent to students in order to watch and learn about the educational content at home before attending the class.

-Achievement: the amount of knowledge that the learner obtains as a result of training and previous experiences, and it is a specific level of school learning efficiency, and it is determined by the teacher through the test. (Ismaili, 2019).

It is procedurally defined as the results of what female students learned in history for the first secondary grade in history as a result of teaching using virtual classrooms, flipped classrooms, through the application (Microsoft 
Teams) and PowerPoint presentations. It is measured by the total score a student obtains in the achievement test, which is prepared by researcher for the purposes of this study.

-The first secondary grade: It is one of the grades of the secondary stage, and it includes first secondary female students who study in the public and private schools in Al-Qasr Directorate of Education during the eleventh academic year; That is, around seventeen years old.

-History curriculum: the textbook that was approved by the Jordanian Ministry of Education in 2016 AD and reprinted in 2017 / $2020 \mathrm{AD}$ in all its schools for all branches of education, and among these branches are firstyear secondary students.

\section{THEORETICAL FRAMEWORK AND PREVIOUS STUDIES}

Information and communication technology has helped educational institutions achieve their goals and meet their needs, especially in light of the Corona pandemic. These institutions are keen to build a knowledge society, and achieve learning and teaching outcomes through e-learning applications in order to supply the demands of the labor market within a strategy that increases the efficiency of learners. The rapid growth in information technology has resulted in the emergence of new technologies in Internet services, such as the third generation and cloud computing. This encourages the educational institution to adopt information technology, integrate it into the educational process and provide learning resources for free (Marshall, 2013).

The philosophy of e-learning stems from providing education to all learners according to their abilities and achieving equal learning opportunities for all learners; to obtain better learning, and deliver learning to learners without being affected by geographical distance, gender or ethnicity. It also helps those whose circumstances prevented them from attending traditional classes, or who have obstacles such as chronic illness or working conditions. It is a movement to new learning without restriction in terms of learners according to their ability and speed (Amr, 2018)

E-learning increases the learner's motivation to learn in an enjoyable way. This helps to establish an unforgettable information among the learners because they are discoverers of information rather than recipients. unlike the traditional method. It breaks the monotony and stagnation in learning and gives learners the freedom to choose the educational content, time and place according to their desire without restrictions (Al-Eid and AlSha'i, 2015).

It can be defined as a distance interactive electronic application based on participatory interactive programs and applications through electronic platforms and tools in order to achieve communication between the parties of the virtual learning process through audio, video and written texts to achieve an educational situation similar to real situation without time and place restrictions.

\section{TYPES OF VIRTUAL CLASSES:}

According to the literature and previous studies related to virtual classrooms, they are classified to three types: a. Synchronous Virtual Class room:They are defined as virtual classes that provide participants with directteaching at the same time where both the teacher and the learners exist at the same time to interact and share content by activating the tools available to them through audio, image, video, interactive whiteboard, text chat, views exchange on a learning topic and skills, and instant feedback. Therefore, these classes are similar to traditional classrooms in terms of the teacher and learners using the content of the educational material in real time in order to be able to communicate and interact face to face as in traditional classes (Abdelrashid \& Sharabi, 2015).

b. Asynchronous Virtual Class room: They are classes that allow indirect interaction between the teacher and the learners. It does not require the presence of the teacher and the learners at the same time when the learning sessions are held, they are not restricted to a place or time. Tasks, educational materials, assessment and learning opportunities are made available without time specificationand according to the learner's choice and desire to participate. They have absolute freedom to choose the appropriate learning time. It is regarded a form of online communication that is not restricted to geographical location (Abdelrashid\&Sharaby, 2015).

c- Virtual blended classes: they are classes that combine both synchronous and asynchronous virtual classes; It provides synchronous and asynchronous learning to learners (Abdelrashid\&Sharaby, 2015).The virtual classroom consists of a set of basic elements and is a component of employing performance in the virtual classroom. Each of (Tonsmann, 2014; Bondi, et al., 2016; Hussen, 2016), refers to these elements as follows:

1. Direct audio and video interaction tools: These tools provide direct interaction between the teacher and the learners, and the learners themselves.An audio and video conversation takes place and the microphone is used to exchange opinions, and a video is used to display the image, and clarify the speakers' personality. Audio and video interaction takes place between the learners about skills.

2.Text Chat: This tool is a means of written or text conversations, exchanged between the teacher and the learners, and the learners themselves. They are important interactive means that do not distract attention during the dialogue.

3. Interactive white board: It is a screen that the teacher and learners see.It presents various explanations, applications and offers; It contains supporting tools, such as: the symbol display tool, the selection tool, the 
drawing tool, shapes, lines, etc. You can write and display stimuli through this board.

4. Application sharing tool: It is a tool for displaying various applications while learning, such as: video presentations, PowerPoint, images and drawings. This tool enables learners to share applications or share the teacher's computer desktop while learning. Virtual classes are characterized by providing an interactive environment for learning; It provides a wide variety of content and tools for communication and expression, audio, image and video sharing, attaching files, and sharing applications. This increases the development of social skills (Kusc, M. \&Arslan, H. 2016).

\section{VIRTUAL CLASSROOM TOOLS:}

There are basic tools used in the virtual classroom. (Saada and Al-Sartawi, 2007; Zaitoun, 2006, Al-Ajrami, 2013, and Khamis, 2009) mention these tools as follows:

1 - Internet relay chat.

2- Real-time Audio with visuals.

3- Application Sharing.

4-The Bach Board electronic board.

5- Short quizzes and opinion polls.

6- internet Browsing.

7- Breakout rooms.

8- Desktop and File Sharing.

\section{THE SECOND AXIS: FLIPPED CLASSROOMS:}

The era in which we live is characterized by rapid development and change in all aspects of life. The change included knowledge and scientific facts as a result of the explosion of knowledge and modern technology. This in turn affected the educational process, its teaching methods, and the development of methods based on the use of technology in education, and one of the most prominent methods is teaching in flipped classrooms (AlTuwaiji, 2017).

This learning is characterized by combining individual learning with group learning, as well as combining faceto-face teaching methods and strategies, and web-based e-learning strategies.)

The educational literature indicates the basic criteria for achieving the success of the flipped classroom strategy as follows (Haroun and Sarhan, 2020):

1. Flexible educational environment: It means the flexibility of the educational system, and the teacher's rearrangement of the learning environment in proportion to the educational situation, learners' levels and needs, and the multiplicity of approaches and methods of teaching, and evaluation.

2. Learning culture: It indicates that the learner's culture is based on the philosophy of learning. To put the learner at the center of the learning processand constantly in the process of forming knowledge positively and effectively, participating in learning.The teacher's role serves as a guide.

3. Academic content: Defining and analyzing the content depends on the decisions the teacher takes according to thelearners' nature and the educational material. The teacher is free to choose the content, focusing on what to present to the learners through direct or cooperative learning, taking into account the appropriate time, the implementation period and the flipped learning procedure within and outside the classroom.

4.The competent teacher: Teacher's preparation, training,professional development, and provision with the necessary competenciesare meant to implement the flipped learning strategy. There is an increasing need for flipped learning for teachers who have the ability to make appropriate decisions, such as switching between direct and indirect teaching through technology.

5. Administrative and technical support: The application of flipped learning requires approval from the administratorsin that it entails following up learners'attendance, the progress of learning, and the need for flexibility in preparing schedules, and conducting evaluation inside and outside the classroom.

THE ROLE OF THE TEACHER AND THE LEARNER IN FLIPPED LEARNING

The learner's role is to watch the educational video and acquire theassociated skills and knowledge, take notes to understand the educational content, actively share ideas and issues contained in the educational materials, initiate questions and comment on learners' observations, perform educational individual and collective activities, and participate in self- and peer evaluation processes (Canzittu), 2016).

Flipped classrooms are characterized by enabling learners to update curricula, use class time more effectively, use modern technologies flexibly, achieve a balance between the objectives of the educational process, use variety of teaching methods based on the integration of technology in education, enhance social communication among teacher and learners, and provide all means of suspense and attention to learners (Abdul Wahed, 2016).

The use of the flipped learning strategy encounters several drawbacks. The teacher is required to exert an extra effort after the official working hours, in addition to his effort during the implementation of the lesson, and the school does not provide the resources that help the teacher to record the video (Al-Zain, 2015). 


\subsection{Previous studies:}

This part reviews a number of previous Arab and foreign studies, and the researcher reviewed a number of these studies related to the subject of the study on the effectiveness of teaching using virtual classrooms and flipped classrooms in developing achievement. The researcher divided these studies into two parts, as follows:

2.1.1 Studies that addressed the effectiveness of teaching using virtual classrooms in developing achievement:

Al-Riyamiya and Al-Najjar (2020) conducted a study to find out the effectiveness of using virtual reality (3D Mozaik) in teaching social studies on developing achievement and visual thinking skills for tenth grade femalestudents. The researcher adopted the experimental method based on a quasi-experimental design with an unequal control group, and the researcher prepared the study tools from an achievement test or a test in visual thinking skills. The study sample consisted of (50) female students from the tenth grade, and were divided into two groups, the experimental group (27) female students, and the control group (23) female students. The study showed that there were statistically significant differences at the significance level $(\propto \leq 0.05)$ between the average scores of the students in the experimental and control groups, the post application in each of the achievement test, and the test of post thinking skills were in favor of the experimental group, and the study recommended the necessity of taking advantage from the 3D Mozaik programmingand virtual reality applications in teaching social studies and other subjects.

Awad (2019) conducted a study aimed at revealing the impact of virtual museums on developing the history material of sixth grade female students in Jordan and their attitudes towards it. The study followed the quasiexperimental approach, and the descriptive survey method for data collection. The researcher prepared a pre and post achievement test of (20) items, and a questionnaire to measure the students' attitudes towards the virtual museum consisting of (20) items. The study sample consisted of (50) female students, divided into two groups, an experimental group (25) female students, and a control group (25) female students, where the experimental group was taught using the virtual curriculum, and the control group was taughtthroughtraditional method. The results of the study showed that there were statistically significant differences between the two groups on the cognitive achievement test, which were taught using the virtual museum,

and the existence of statistically significant differences between the means of theexperimental study members' scores on the scale of attitudes towards the virtual museum between the pre and post scales, which indicates the improvement of the female students' attitude towards the virtual museumafter learning, the study recommends inviting history supervisors and teachers to use educational software such as virtual museums to improve learning of history, develop positive attitudes, and increase the effectiveness of educational programs based on the integration of technology to increase learners'achievement in the field of social studies. It also recommends conducting similar studies to address other variables such as students' academic level, and experience in the field of e-learning.

2.1.2 Studies that dealt with the effectiveness of teaching using flipped classrooms in developing achievement:

Al-Houri (2020) conducted a study aimed at investigating the impact of the use of flipped learning on the achievement of sixth grade students in Jordan. The study sample consisted of (53) male and female students from Al QadisiyahBasic School for Girls, and Ruqayah Bint Al-Rasoul Basic School for Girls. The study adopted the quasi-experimental approach..An achievement test was prepared, and the unit entitled decent living and the duration of traffic safety was analyzed. The results of the study showed a statistically significant difference of flipped learning in the achievement of female students between the control and experimental group and in favor of the experimental group.

Al-Ghamdi and Al-Ansaristudy (2018) sought to investigate the effectiveness of flipped learning in developing self-learning skills and cognitive achievement in the social and national studies textbook for first secondary female students in Taif. The study sample consisted of (68) female students, divided into two groups, where the first group, (34) female students, studied through computerized thinking maps, and the second group, (34) female students learned through the traditionalmethod. The results of the study showed that there were statistically significant differences in favor of the group that studied using flipped learning, and there were also statistically significant differences between the two groups in each of thinking skills scale for self-learning, and the achievement test.

\subsection{METHODOLOGYAND DESIGN:}

This chapter deals with a description of the study's methodology, population and sample, data collection tools, procedures for verifying their validity and reliability, study variables, study implementation procedures, and statistical treatments.

\subsection{STUDY APPROACH:}

The quasi-experimental approach was used to identify the effectiveness of the virtual and flipped classes in 
developing the achievement of first-year secondary female students, in the history subject, in the Qasr District.

\subsection{STUDY POPULATION:}

The study population consisted of all female students in the first secondary,scientific branch in public schools in the Directorate of Education in Al-Qasr District for the first semester of the year 2020/2021 AD. The number was (298) students, distributed among (10) schools from female schools, and (13) sections, according to the statistics of Qasr Directorate of Education for the academic year 2020/2021 AD.

\subsection{STUDY SAMPLE:}

Serfa Secondary Comprehensive School for Girls was purposively selecteddue to the availability of appropriate computer techniques, and for theteachers' cooperation to conduct this study. there is more than one section for the first scientific secondary grade. Section (A) was chosen as the first experimental group: it is a group of students of the first secondary grade, scientific, at Serfa Secondary Comprehensive School for Girls. They studied a unit of the history of Jordan for the eleventh grade, which is the unit of Jordan in the early Islam (the Rashidun and Umayyad era), using virtual classes via Microsoft Teams application, and section (B) as the second experimental group: a group of first secondary students at the Serfa Comprehensive Secondary School for Girls and they studied two units in the history of Jordan for the eleventh grade, which is the unit of Jordan in the early Islam (The Rashidun and Umayyad Era) using WhatsApp application by sending links that include the educational lessons of the two units of material to their group. It is sent a day before the start of the class, and at the time of the class, the educational material and its content will be discussed through the Microsoft Teams application.

\subsection{STUDY TOOLS:}

\section{FIRST- ACHIEVEMENT TEST:}

The researcher constructed an achievement test for first secondary female students in a unit in the history of Jordanfrom the Jordanian curriculum scheduled for the 2012/2021 academic year: (Jordan in the early Islam, the Rashidun and Umayyad era)after analyzing the content, and extracting the behavioral objectives according to Bloom's taxonomy. Then a specification table was constructed as appendix (a, b) shows. In light of the specification table, the achievement test was constructed. The test consisted of (40) multiple-choice items, with four alternatives for each item. So the highest mark is 40 and the lowest mark is zero. The duration of the test was determined according to the time taken by the first female studentand the last student in the pilotsample. The arithmetic mean was then calculated where the average duration was (40) minutes.

\subsection{TEST VALIDITY:}

The researcher verified the validity of the achievement test by relying on thearbitrators' evaluations, where the test was distributed in its initial form to (15) arbitrators with experience and specialization in Jordanian universities in the fields of curricula, teaching methods, measurement and evaluation, educational supervisors and teachers who teach social subjects, especially history, in Qasr Directorate of Education. They expressed their opinions and observations on the test items in terms of content and language. The researcher depended on an agreement percentage $(80 \%)$ as criterion. In light of the arbitrators' observations and suggestions, some items were added, deleted or modified.

The validity of the test was also verified using the internal consistency method, which is one of the construct validity methods, and the Pearson correlation coefficient was extracted for each test item with the total score as table (2) explains 
Table (2): The correlation coefficient of each item of the achievement test with the total score of the test

\begin{tabular}{|c|c|c|c|c|c|}
\hline $\begin{array}{c}\text { Item } \\
\text { no. }\end{array}$ & $\begin{array}{c}\text { The correlation } \\
\text { coefficient of the total } \\
\text { score }\end{array}$ & $\begin{array}{r}\text { Item } \\
\text { no. }\end{array}$ & $\begin{array}{r}\text { The correlation } \\
\text { coefficient of the } \\
\text { total score }\end{array}$ & $\begin{array}{c}\text { Item } \\
\text { no. }\end{array}$ & $\begin{array}{c}\text { The correlation } \\
\text { coefficient of the total } \\
\text { score }\end{array}$ \\
\hline 1 & $0.59^{*}$ & 15 & $0.70^{*}$ & 29 & $0.80^{*}$ \\
\hline 2 & $0.78^{*}$ & 16 & $0.61^{*}$ & 30 & $0.51^{*}$ \\
\hline 3 & $0.63^{*}$ & 17 & $0.62^{*}$ & 31 & $0.50^{*}$ \\
\hline 4 & $0.59^{*}$ & 18 & $0.58^{*}$ & 32 & $0.81^{*}$ \\
\hline 5 & $0.71^{*}$ & 19 & $0.73^{*}$ & 33 & $0.60^{*}$ \\
\hline 6 & $0.66^{*}$ & 20 & $0.60^{*}$ & 34 & $0.77^{*}$ \\
\hline 7 & $0.86^{*}$ & 21 & $0.58^{*}$ & 35 & $0.70^{*}$ \\
\hline 8 & $0.61^{*}$ & 22 & $0.70^{*}$ & 36 & $0.66^{*}$ \\
\hline 9 & $0.50^{*}$ & 23 & $0.82^{*}$ & 37 & $0.77^{*}$ \\
\hline 10 & $0.82^{*}$ & 25 & $0.77^{*}$ & 38 & $0.51^{*}$ \\
\hline 11 & $0.55^{*}$ & 26 & $0.80^{*}$ & 39 & $0.50^{*}$ \\
\hline 12 & $0.89^{*}$ & 27 & $0.64^{*}$ & 40 & $0.81^{*}$ \\
\hline 13 & $0.70^{*}$ & 28 & $0.61^{*}$ & & \\
\hline 14 & $0.59^{*}$ & $0.69^{*}$ & & \\
\hline
\end{tabular}

*Statistically significant at the level of significance $(\alpha \leq 0.05)$.

DIFFICULTY AND DISCRIMINATION COEFFICIENTS FOR ACHIEVEMENT TEST ITEMS:

The educational literature indicates that a good test whose items includes a wide gradation between the degrees of ease and difficulty. In order to be able to distinguish among the examinees' levelthrough the test. To demonstrate this, the coefficients of difficulty were calculated for the items of the achievement test by calculating the percentage of the correct answer among the total answers for each of the test items, and the discrimination coefficients for the test items were calculated by arranging the results of the students according to the total score in descending order, then the researcher determined the high group (27\%) compared to the lower group (27\%), as shown in Table No. (3).

Table (3): Difficulty and discrimination coefficients for the test items

\begin{tabular}{|c|c|c|c|c|c|}
\hline Item & $\begin{array}{c}\text { Difficulty } \\
\text { coefficient }\end{array}$ & $\begin{array}{c}\text { Discrimination } \\
\text { coefficient }\end{array}$ & item & $\begin{array}{c}\text { Difficulty } \\
\text { coefficient }\end{array}$ & $\begin{array}{c}\text { Discrimination } \\
\text { coefficient }\end{array}$ \\
\hline 1 & 0.50 & 0.70 & 21 & 0.66 & 0.50 \\
\hline 2 & 0.61 & 0.47 & 22 & 0.70 & 0.55 \\
\hline 3 & 0.38 & 0.58 & 23 & 0.32 & 0.35 \\
\hline 4 & 0.76 & 0.70 & 24 & 0.35 & 0.80 \\
\hline 5 & 0.59 & 0.83 & 25 & 0.55 & 0.60 \\
\hline 6 & 0.37 & 0.71 & 26 & 0.41 & 0.41 \\
\hline 7 & 0.55 & 0.80 & 27 & 0.47 & 0.70 \\
\hline 8 & 0.66 & 0.60 & 28 & 0.63 & .660 \\
\hline 9 & 0.48 & 0.50 & 29 & 0.70 & 0.69 \\
\hline 10 & 0.55 & 0.49 & 30 & 0.55 & 0.49 \\
\hline 11 & 0.58 & 0.70 & 32 & 0.44 & 0.50 \\
\hline 12 & 0.40 & 0.65 & 33 & 0.49 & 0.76 \\
\hline 13 & 0.50 & 0.50 & 34 & 0.57 & 0.71 \\
\hline 14 & 0.49 & 0.60 & 35 & 0.48 & 0.690 \\
\hline 15 & 0.61 & 0.63 & 36 & 0.60 & 0.51 \\
\hline 16 & 0.55 & 0.39 & 37 & 0.63 & 0.70 \\
\hline 17 & 0.40 & 0.45 & 38 & 0.70 & 0.52 \\
\hline 18 & 0.45 & 0.60 & 40 & 0.65 & \\
\hline 19 & 0.55 & 0.40 & 0.70 & & \\
\hline 20 & 0.70 & & & & 0.51 \\
\hline
\end{tabular}

\subsection{TEST RELIABILITY:}

After conducting the necessary modifications in the light of the arbitrators' opinions, the test's reliability was verified through (Test Retest) after a couple of weeks on apilot sample consisting of (20) female students from the study population (Serfa Comprehensive Secondary School for Girls inQasr Directorate of Education) and outside its sample. The value of the reliability coefficient was $(0.93)$, and these values are considered scientifically acceptable and indicate a relatively high reliability that can be trusted andthis indicates the validity 
of its application to the study sample.

\subsection{STUDY VARIABLES:}

The research design of this study includes the following variables:

1.The independent variable: the teaching method and its levels (teaching with virtual classes, teaching with flipped classes) using the Microsoft Teams application.

2. The dependent variables: the achievement test.

\subsection{STUDY PROCEDURES:}

a. Control procedures (equivalence): To ensure that the two groups of the study were equivalent, the achievement test was applied to the twostudygroups before conducting the study.

b. Experimentation procedures: The experimentation procedures were performed according to the following steps:

-Thestudysample was divided into two experimental groups by the simple random method, where the first experimental group studied a unit entitled Jordan in the early Islam (the Rashidun and Umayyad era), by the virtual classroom method, and the second experimental group studied the same unit, by the flipped classroom method.

\subsection{THE ACHIEVEMENT TEST WAS APPLIED BEFORE AND AFTER THE STUDY:}

-The female students were trained how to use the virtual classroom through explanations and clarifications via WhatsApp groups, sending an explanatory video, and identifying the function and how to use each of the virtual classroom tools through an explanatory video.

-The educational material was designed as virtual classroomsand flipped classes through the (ADDIE) model for the design of education. This model consists of the following stages:

1. Analysis: At this stage, the general objectives, the educational material, and the educational tasks as well as the target group were defined.

2.Design: In view of the previous stage, the behavioral educational objectivesandthe educational contentwere determined, organized and arranged, the activities, formative tests, and the appropriate educational aids were identified,as well as discussions, dialogues, and opinionand ideasexchange among group members were conducted. The educational content was prepared to fit the virtual classroom sessions through videos, electronic links, and presentations. The previous content had also been prepared to match the flipped classrooms. The specifications of the educational material were determined on paper in the form of diagrams and drawings to be uploaded to the computer.

3. Development: At this stage, the specifications of the educational material to be taught through virtual classrooms and flipped classrooms werechanged. These specifications include: educational objectives, content, media, activities, and calendar, to electronic physical formats, and they had been uploaded to Microsoft Teams.

4.Implementation (Usage): At this stage, the educational material was taught according to virtual and flipped classrooms toapilot sample of 20 female students. Students' learning was observed and the problems and difficulties they had were observed. Amendments and improvements were then made.

5. Evaluation: The virtual and flipped classes were presented to (7) arbitrators of academic staff specializing in educational technology, educational supervisors, and computer teachers, and they were asked to express their opinions, and the amendment was made according to their observations.

\section{TO ANSWER THE STUDY QUESTION:}

Were there statistically significant differences $(\alpha=0.05)$ in the development of achievement among first secondary female students in the history subject due to the teaching method (flipped classrooms, virtual classrooms)?

To answer this question, the researcher extracted the arithmetic means, standard deviations in the pre and post application, as well as the modified arithmetic means, according to the group variable (virtual classrooms, flippedclassrooms) as table (4) shows.

Table No. (4): Arithmetic means and standard deviations of the performance of the two groups in the post application of the achievement test.

\begin{tabular}{|c|c|c|c|c|c|c|}
\hline \multirow[t]{2}{*}{ variable categories } & \multicolumn{2}{|c|}{ pre measurement } & \multicolumn{2}{|c|}{ Post measurement } & \multirow{2}{*}{$\begin{array}{c}\text { adjusted } \\
\text { arithmetic } \\
\text { mean }\end{array}$} & \multirow{2}{*}{$\begin{array}{c}\text { standard } \\
\text { error }\end{array}$} \\
\hline & $\begin{array}{c}\text { arithmetic } \\
\text { mean }\end{array}$ & $\begin{array}{l}\text { standard } \\
\text { deviation }\end{array}$ & $\begin{array}{l}\text { arithmetic } \\
\text { mean }\end{array}$ & $\begin{array}{l}\text { standard } \\
\text { deviation }\end{array}$ & & \\
\hline virtual classrooms & 11.39 & 4.26 & 12.22 & 3.55 & 12.10 & 1.27 \\
\hline flipped classrooms & 13.23 & 6.53 & 27.45 & 7.83 & 27.58 & 1.30 \\
\hline
\end{tabular}

data in Table (4) indicated that there were apparent differences in the level of performance of the two groups (virtual, flipped classrooms) in the achievement test in the post application, as well as in the modified arithmetic mean where the modified arithmetic mean for the group of virtual classrooms was (12.10) and for the 
group of flipped classrooms was (27.58).To test the significance of these differences; one-way analysis of variance (Ancova) was used to compare the performancelevelof the study sample in the achievement test in the post-application according to the (group) variable. the performancelevelin the pre-application (before teaching) is regarded the covariate (control variable). Table No. (5) shows the results.

Table No. (5): One-way analysis of variance (Ancova) to examine the differences in the post application of the achievement test.

\begin{tabular}{|c|c|c|c|c|c|c|}
\hline $\begin{array}{c}\text { source of } \\
\text { variation }\end{array}$ & $\begin{array}{c}\text { sum of } \\
\text { squares }\end{array}$ & $\begin{array}{c}\text { degrees of } \\
\text { freedom }\end{array}$ & $\begin{array}{c}\text { mean } \\
\text { squares }\end{array}$ & $\begin{array}{c}\text { f) } \\
\text { value( }\end{array}$ & $\begin{array}{c}\text { level of } \\
\text { significance }\end{array}$ & $\begin{array}{c}\text { effect size } \\
\text { Eta } \\
\text { squared }\end{array}$ \\
\hline Group & 2616.899 & 1 & 2616.899 & 71.219 & $0.000^{*}$ & 0.629 \\
\hline Error & 1543.259 & 42 & 36.744 & & & \\
\hline total & $21,581,000$ & 45 & & & & \\
\hline corrected total & 4176.000 & 44 & & & & \\
\hline
\end{tabular}

Statistically significant at the significance level $(\alpha=0.05)^{* *}$

Data in Table (5) indicated that (F) value which is (71.219), and the level of the accompanying significance $(0.00)$, which is less $(\alpha=0.05)$ showed that there were statistically significant differences in the postmeasurement of the achievement test, after adjusting the pre performance according to the group variable (virtual classrooms, flipped classrooms).By referring to theadjusted arithmetic means in Table (5), it appeared that the adjusted arithmetic mean of the virtual classroomsgroup was(12.10) and for the Flipped Classroom group was (27.58), which indicated a higher level of achievement between the flipped classroom group compared to the virtual classroom group. This confirms the effect of flipped classrooms on developing the achievement of first secondary female students compared to virtual classroomsgroup.It also confirms the calculated effect size, which amounted to $(62.9 \%)$, a value that reflects the existence of a significant impact according to the "Cohen" classification, which confirms the effect of flipped classes in developing the achievement of firstsecondary female students compared to virtual classes group. Figure No. (1) shows the variance between groups in the post application of the achievement test, according to the adjusted arithmetic means.

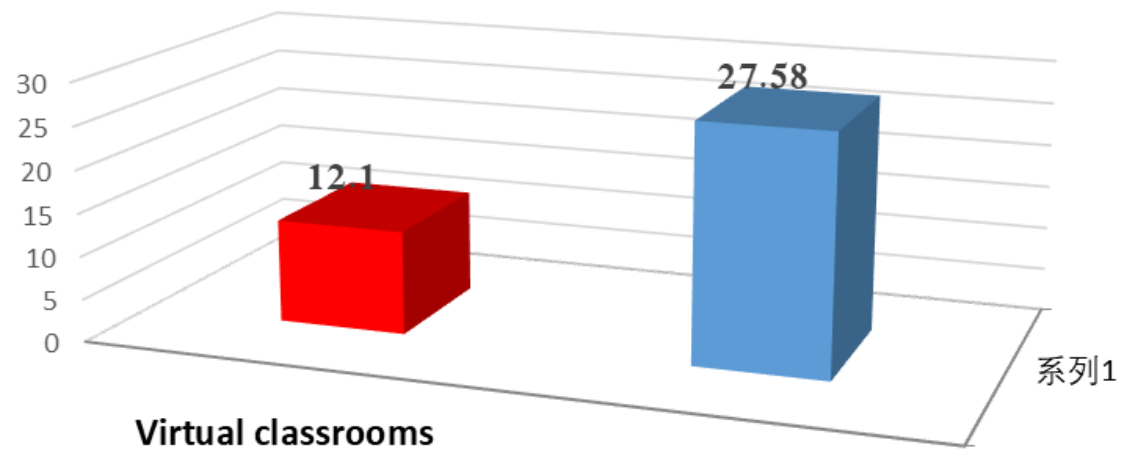

Flipped classrooms

Figure No. 1: The variance between groups in the post application of the achievement test according to the adjusted arithmetic means.

The researcher attributed this result to the constructivist theory, which indicated that the learner is the one who construct knowledge instead of receiving itwhere the learner was given the role of the active learner, and the freedom to learn through the flipped classroom strategy, which achieved cooperation and interaction among learners, and was positively reflected on raising their level of achievement (Ibrahim, 2015). Virtual and flipped classrooms arean application of the principles of social constructivist theory in that they create a virtual environment that simulates reality, applylearning and social communication on a continuous basis, and support cooperative learning among learners.In virtual environment, learning isbelievedto be interpretation, construction and modification to understand reality and flipped classes provided learning opportunities for learners to apply their experiences in order to construct knowledge and interact with learning resources and educational material. Flipped learning also provided richinformation sources such as technology papers, and conversation papers. Needless to say, it enhances cooperation to access information (Anekew, 2017). 
The researcher attributes this result to the flipped learning experiences represented in increasing the learners' abilities to organize self-learning, providing learner independence (Lai \& Hwang, 2016).In addition, it transfers the educational material outside the classroom, and establishes a learner-centered learning environment (Bergmann \&Sams, 2012). Flipped classrooms also achievemore interactive class time and learners use modern technologies flexibly. They achieve balance between the objectives of the learning process, diversify the use of technology-based teaching methods in education, enhance social communication between the teacher and learners, and provid means of suspense and attention. (Abdul Wahed, 2016).

\subsection{RECOMMENDATIONS:}

1- Providing a framework on the strategy of virtual classrooms and flipped classrooms in teaching history. For specialists, educators, researchers, educational supervisors and school administrators to benefit from while performing their supervisory duties where teachers are directed to adopt modern and appropriate teaching strategies, especially in light of distance learning in teaching history to develop the strategies used in history at the secondary level.

2- Integrating modern technology into learning as a contemporary and important educational approach in education in general with the aim of mastering learning.

3- Presenting a procedural model for those concerned in the Ministry of Education to use the strategy of virtual classrooms and flipped classrooms in developing academic achievement in the subject of history when developing curricula.

\section{REFERENCES}

-Al-Ajrami, Sameh. (2013). The effectiveness of a proposed program based on ellumniate virtual classrooms in developing effective teaching skills among student teachers at Al-Quds Open University and their attitudes towards it. Al-Manara Journal, 19(3), 313-350.

-Al-Zahrani, Abdul Rahman. (2015). The effectiveness of the flipped classroom strategy in developing the level of cognitive achievement for the e-learning course among students of the College of Education at King Abdulaziz University. Journal of the College of Education, 2 (162), 471-502.

-Al Eqab, Abdullah. (2018). The effectiveness of blended learning on the level of students' academic achievement and their attitudes towards in the College of Social Sciences. North Journal of the Humanities, 1(3), 109-135.

-Abdel Wahed, Ali. (2016). Implementation of the flipped classroom strategy in teaching Arabic to nonnative speakers. Paper presented to the Conference on Linguistic and Literary Studies in the Light of Contemporary Challenges "Towards a Modern Vision of the situation of Linguistic and European Challenges" Al-Madinah International University, Malaysia.

-Al-Tuwaiji, Ahmed. (2017). The effectiveness of the flipped learning strategy in the academic achievement of the critical thinking skills course among students of the University of Science and Technology, Aden Branch. Specialized International Educational Journal, 6(9), 48-62.

-Al-Harthy, Sa'd. (2018). The effectiveness of the learning by playing strategy in developing creative thinking skills and attitudes towards social and national studies for third-grade intermediate students in the Kingdom of Saudi Arabia. Journal of the College of Education, 174(1), 754-783.

-Abu Maileq, Karam. (2020). Obstacles and difficulties that e-learning in Palestinian universities encounter. Journal of Studies in the Humanities and Social Sciences, 3(4), 313-349.

-Amr, Maram. (2018). The degree to which faculty members in private Jordanian universities use elearning management systems (LMS) and the factors that limit that use from their perspective. Unpublished Master's Thesis, Middle East University, Jordan.

-Ismaili, Yamina. (2019). Thinking patterns and levels of academic achievement. Amman: Jordan, Al-Yazuri Scientific House.

-Al-Ghamdi, Maha and Al-Ansari, Wedad. (2018). The effectiveness of flipped learning in developing selflearning skills and cognitive achievement in the social and national studies course for first secondary school students in Taif. International Journal of Educational Research, 3(42), 197-236.

-Houry, Madian. (2020). The effect of using the flipped learning strategy on the achievement of sixth grade students in the subject of national education in Jordan. Palestine University Journal for Research and Study, (10), 58-80.

-Awad, Asmaa. (2019). The effect of implementation virtual museums in developing the history textbook for sixth grade female students in Jordan and their attitudes towards it. Unpublished Master's Thesis, The Hashemite University, Jordan.

-Al-Riyamiya, Basma and Al-Najjar, Noor. (2020). The effectiveness of using virtual reality (3DMozaik) in teaching social studies on developing the achievement and visual thinking skills of tenth grade female students. Educational Journal, 137(34), 291-336. 


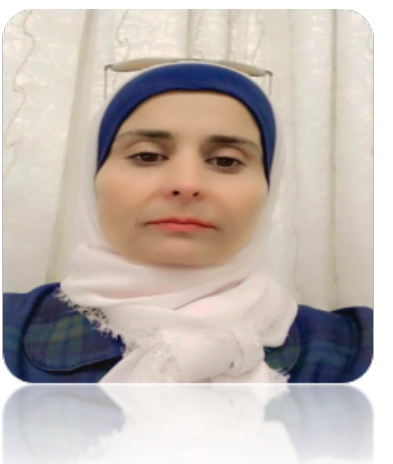

Ms. EHTERAM SALEEM AMMAN

SALMAN ALLASASMEH JORDAN - 